\title{
Correction to: Organ donation in principle and in practice: tensions and healthcare professionals' troubled consciences
}

\author{
Laura L. Machin ${ }^{1} \cdot$ Jessie Cooper $^{2} \cdot$ Heather Dixon $^{3} \cdot$ Mark Wilkinson $^{4}$
}

Published online: 27 February 2021

(C) Springer Nature Limited 2021

\section{Correction to: BioSocieties https://doi.org/10.1057/s41292-020-00219-z}

In the original publication of the article, the second author's affiliation was published incorrectly and the correct affiliation is given in this correction.

The original article has been corrected.

Publisher's Note Springer Nature remains neutral with regard to jurisdictional claims in published maps and institutional affiliations.

The original article can be found online at https://doi.org/10.1057/s41292-020-00219-z.

Laura L. Machin

1.machin@lancaster.ac.uk

1 Lancaster Medical School, Faculty of Health and Medicine, Lancaster University, Lancaster, UK

2 City, University of London, London, UK

3 Lancashire Teaching Hospitals NHS Foundation Trust, Preston, UK

4 University Hospitals of Morecambe Bay NHS Foundation Trust, Lancaster, UK 